\title{
Development of Nanotechnology in India: A Review
}

\author{
Namita Rajput \\ Govt. Polytechnic College Balaghat (M.P.)India 482001
}

\begin{abstract}
Nanotechnology today is regarded as a revolutionary technology that can help address key needs relating to energy, environment, health, agriculture, electronics, textiles, construction, water treatment, food processing and cosmetics in developing countries. Most of these applications are very much relevant for a developing country like India. The government of India has been investing in nanotechnologies since 2001.Nanotechnology development in India is at a initial stage with policy initiatives directed towards promoting research and development. It is largely a government led initiative and industry participation is still emerging. This discussion paper attempts to capture the nanotechnology development in India by stressing the various initiatives taken by the government to promote basic $R \& D$ in it including global trends, the major factors involved and the state of regulatory framework existing in the country. the major challenges facing the adoption and diffusion of nanotechnology.
\end{abstract}

Keywords: bulk matter, global trends, interdisciplinary, nano-scale, Nanotechnology.

\section{Introduction}

Nanotechnology is usually conceptualized as the understanding and control of matter at the nano-scale. At this scale, the physical, chemical and biological properties of materials differ from that of bulk matter, which enable novel applications[1-2]. The application of these properties to innovative products and processes is said to have such enveloping consequences that the 21 st century is already being called as the 'nano-century'. Several countries in the Global South, including India, have taken up initiatives this field After year 2000 [3-4].

Since Richard Feynman's well known statement made in 1959, "There is a plenty of room at the bottom," nanotechnology has transformed how products are fabricated. Like other disruptive technologies, it is catalyzing economic growth [5-8]. Early nanotechnology milestones included the first molecular device in 1974 [9] and the scanning tunnelling microscope in 1981 [10], the understanding of the carbon nanotube [11], and the DNA nanomechanical device [12]. According to Robert Floyd Curl, Jr., Nobel Prize Winner in Chemistry in 1996, Indian craftsmen used nanotechnology in Wootz steel as well as in paintings. Our ancestors have been unwittingly using the technology for over 2,000 years and carbon nano for about 500 years. However the Government of India has been systematically investing in nanotechnology since 2001[4]. At nano-scale, some materials gain radically new characteristics and functionalities that can be opens up new areas for enquiry and applications in various sectors [13-14].

\section{Global Trends}

Worldwide governments have launched many nanotechnology-specific programmes to use the potentialities of nanotechnology for social and economic gains. In 2005 itself, more than 62 countries launched national nanotechnology-specific activities world over [15]. The research and development (R\&D) effort was significantly promoted world over with the USA announcement in 2001 of the National Nanotechnology Initiative (NNI) . Most advanced countries have based their own programmes on the groundwork laid by the NNI. The NNI is the most comprehensive R\&D programme in nanoscience and technology in the world. The focus of NNI is on research and development of nanoscale science and technology for economic benefit and national security [16]. Table 1 provides an overview of the nanotechnology initiatives by some developed and emerging economies [13].

Table1: Nanotechnology government initiative and investment in some of the major economies

\begin{tabular}{|c|c|c|c|c|}
\hline Country & Key coordinating Body & $\begin{array}{c}\text { Nanotechnology Initiative (Yearof } \\
\text { Commencement) }\end{array}$ & Funding & Key Areas \\
\hline US & $\begin{array}{l}\text { Multiagency Governance at } \\
\text { Various Levels. Command } \\
\text { and Control Mode. } \\
\text { Nanoscale Science } \\
\text { Engineering and Technology } \\
\text { Subcommittee }\end{array}$ & $\begin{array}{c}\text { National Nanotechnology Initiative } \\
(2000)\end{array}$ & $\begin{array}{l}\text { USD } 1.5 \text { billion } \\
\text { in } 2009\end{array}$ & $\begin{array}{l}\text { All aspects of nano- } \\
\text { technology }\end{array}$ \\
\hline Japan & $\begin{array}{l}\text { No Specific Coordinating } \\
\text { Body }\end{array}$ & $\begin{array}{c}\text { The Atom Technology Program } \\
\text { (1992) } \\
\text { Nanotechnology and Materials } \\
\text { Program (2001) }\end{array}$ & USD 250 million & $\begin{array}{l}\text { Nano- electronics, } \\
\text { nanomaterials }\end{array}$ \\
\hline
\end{tabular}


Development Of Nanotechnology In India: A Review

\begin{tabular}{|c|c|c|c|c|}
\hline South Korea & $\begin{array}{l}\text { Ministry of Education, } \\
\text { Science and Technology, } \\
\text { Ministry of Knowledge } \\
\text { Economy }\end{array}$ & $\begin{array}{c}\text { Korean National Nanotechnology } \\
\text { Initiative (KNNI),2001-05 (Phase I), } \\
\text { 2006-10 9Phase II }\end{array}$ & $\begin{array}{l}\text { 2001- } 10 \\
\text { USD } 2 \text { billion. }\end{array}$ & $\begin{array}{l}\text { ICT } \\
\text { applications, } \\
\text { e.g. high density } \\
\text { memory, displays }\end{array}$ \\
\hline Taiwan & $\begin{array}{l}\text { National Science Council, } \\
\text { Department of Industrial } \\
\text { Technology }\end{array}$ & $\begin{array}{c}\text { Taiwanese National Nanotechnology } \\
\text { Program } 2003 \text { (Phase I), 2009-14 } \\
\text { (Phase II) }\end{array}$ & $\begin{array}{l}\text { USD } 550 \text { million } \\
\text { USD } 685 \\
\text { million. }\end{array}$ & $\begin{array}{l}\text { ICT } \\
\text { applications primarily } \\
\text { opto- electronics }\end{array}$ \\
\hline China & $\begin{array}{l}\text { National Steering } \\
\text { Committee for Nanoscience } \\
\text { and Nanotechnology }\end{array}$ & $\begin{array}{l}\text { National Steering Committee for } \\
\text { Nanoscience and Nanotechnology } \\
\qquad(2000)\end{array}$ & \begin{tabular}{|l|}
$2001-05$ \\
USD 250-300 \\
million. \\
2006-10 \\
USD 760 \\
million.
\end{tabular} & $\begin{array}{l}\text { Nanomaterials, and } \\
\text { ICT applications }\end{array}$ \\
\hline India & $\begin{array}{l}\text { Multi-agency DST } \\
\text { (Initiation \& } \\
\text { implementation of NSTI \& } \\
\text { Nano Mission) } \\
\text { DIT, DBT, CSIR, DRDO, } \\
\text { ICMR, ISRO, DAE }\end{array}$ & $\begin{array}{c}\text { Nano Science and Technology } \\
\text { Initiative } \\
(2001-06) \\
\text { Nano Mission (2007-12) } \\
\text { DIT Nanoelectronics initiative } 2004 \\
\text { onwards }\end{array}$ & $\begin{array}{l}\text { USD } 16 \text { million (NSTI) } \\
\text { USD } 250 \\
\text { million (Nano } \\
\text { Mission)* }\end{array}$ & $\begin{array}{l}\text { Nanomaterials, } \\
\text { biomedical, } \\
\text { electronics, energy } \\
\text { (solar), water }\end{array}$ \\
\hline
\end{tabular}

Globally, governments currently spend about US\$ 10 billion per year on nanotechnology research and development. By the end of 2011, the total government funding for nanotechnology research worldwide was more than US\$ 65 billion, which is to rise to US\$ 100 billion by 2014 and nearly a quarter of a trillion dollars have been invested into nanotechnology by 2015 (Cientifica 2011). Investment in nanotechnology worldwide has grown rapidly in future. This may be attributed to considerable socio-economic promise offered by nanotechnology [17-18]. In terms of patenting, according to studies carried out by Statnano (2013), 27,350 patents had been published by the end of 2012 in United States Patent and Trademark Office (USPTO), among which 57 per cent were published by the US, giving the first rank to this country while Japan, Republic of Korea, Taiwan and Germany held the next ranks. India ranked $18^{\text {th }}$ with 117 published patents at USPTO. Fig.1 show the categorization of nanotechnology products across countries indicates a concentration in the fields of health and fitness products (cosmetics, clothing, personal care and sporting equipment) [17].

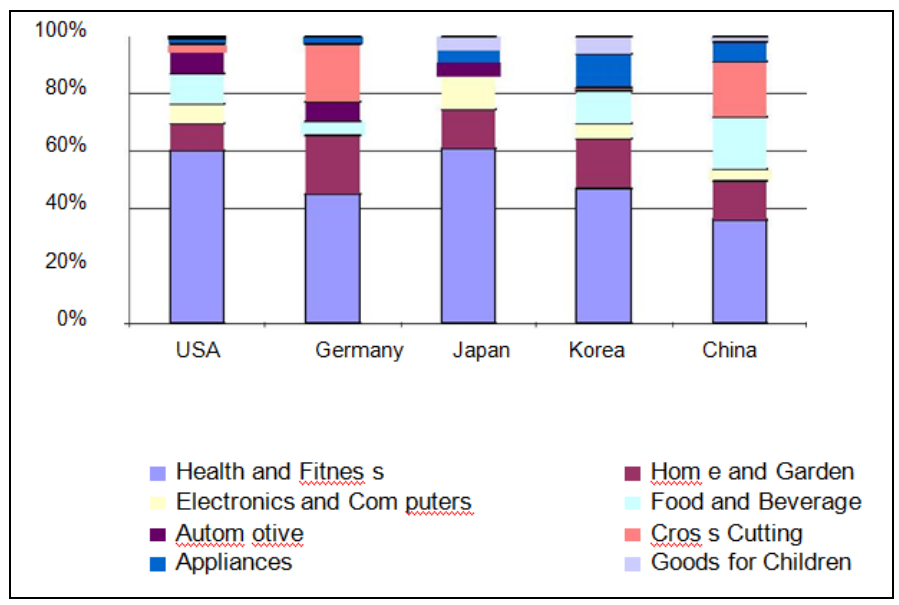

\begin{tabular}{|l|r|}
\hline Country & $\begin{array}{r}\text { Number of } \\
\text { products }\end{array}$ \\
\hline USA & 563 \\
\hline Germany & 78 \\
\hline Japan & 43 \\
\hline Korea & 139 \\
\hline China & 56 \\
\hline
\end{tabular}

Fig. 1 Percentage shares of different categories of nanotechnology products by country, October 2009. Source :Woodrow Wilson International Center for Scholars (see www.nanotechproject.org)

\section{Importance For Developing Countries}

Nanotechnology promises to deliver novel products and processes or enhance the performance of existing ones across sectors. Worldwide, public sector research and development in the nanotechnology sphere is thriving in several developed and as well as developing nations. It cannot only provide solutions in high technology but also world's most pressing problems especially those faced by developing and impoverished 
countries such as environment, water purification, agriculture, energy, health and in a host of other products and services. Several industry related sectors like pharmaceuticals, electronics, automobiles, textile, chemicals and manufacturing sector, information technology and communications as well as biotechnology appear poised to gain from nanotechnology applications. Thus it appears that nanotechnology could impact social development, economies and businesses the world over. This has motivated developing countries to channelize their scarce resources for increasing their capacity and capability in nanotechnology. Public investments and strategic nanotechnology initiatives have been undertaken in countries like India, China, Brazil, South Africa and Korea[19-20].

\section{Evolution Of Nanotechnology In India}

The $9^{\text {th }}$ Five-Year Plan (1998-2002) had mentioned for the first time that national facilities and core groups were set up to promote research in frontier areas of S\&T which included superconductivity, robotics, neurosciences and carbon and nano materials. Planning Commission supported number of such R\&D programmes under basic research $[16,21]$. However, the thrust came with the launch of "Programme on Nanomaterials: Science and Devices" in 2000 by the Department of Science and Technology (DST).

In 2001-2002, the DST set up an Expert Group on "Nanomaterials: Science and Devices". The Government identified the need to initiate a Nanomaterials Science and Technology Mission (NSTM) in the $10^{\text {th }}$ Five Year Plan (2002-07) after taking into consideration the developments in nanotechnology[22].

The National Nanoscience and Nanotechnology Initiative (NSTI) was launched in October, 2001 by Department of Science and Technology of the Ministry of Science. The motive of NSTI in was to create research infrastructure and promote basic research in nanoscience and nanotechnology. It focused on various issues relating to infrastructure development, basic research and application oriented programmes in nanomaterial including drugs/drug delivery/gene targeting and DNA chips. Fig. 10 exhibits the major initiatives during the $10^{\text {th }}$ plan period [13].

The Eleventh Five-Year Plan (2007-2012) categorically mentioned projects to create high value and large impact on socio-economic delivery involving nano material and nano devices in health and disease. The generous Eleventh Five Year Plan Budget allocation of Rs. 1000 crore was earmarked for the Nano Mission when it was launched in 2007 [23] . Accordingly, on 3 May 2007, a Mission on Nano Science and Technology (Nano Mission) was launched by the DST to foster, promote and develop all aspects of nanoscience and nanotechnology which have the potential to benefit the country. Fig. 11 exhibits the major initiatives undertaken during the $11^{\text {th }}$ plan period. In the Twelfth Five Year Plan (2012-2017) too, the government gave its approval for continuation of the Mission on Nano Science and Technology (Nano Mission) in its Phase-II at a total cost of Rs. 650 crore. Its focus is on product development and commercialization for markets and consumers [24].

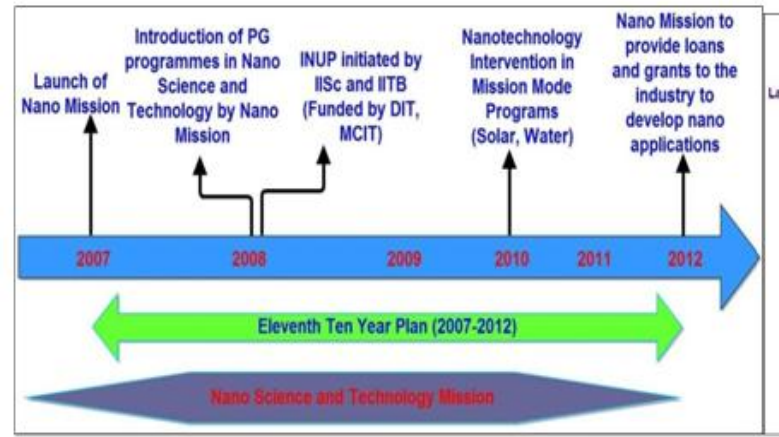

Fig 2 : Major initiatives in nanotechnology (2001-2007)

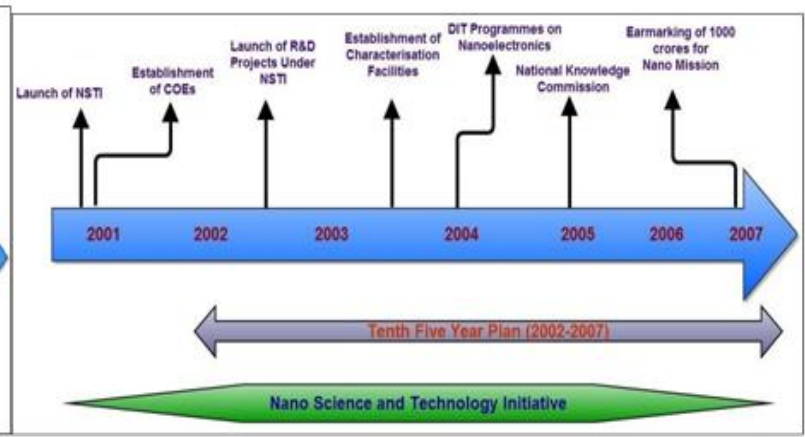

Fig 3 : Major initiatives in nanotechnology (2007-2012)

Source: Constructed from DST (dst.gov.in/scientific-programme/ser-nsti.htm), (Bhattacharya, et al. 2011), Discussions with DST-Nano Mission, Department of Information Technology.

In the beginning during NSTI period Nano Mission Council supported few institutions through identifying key researchers engaged in core nanotechnology field and providing them funding. Afterward with enhanced funding and more sophisticated and capital intensive equipments, eleven Units/Core Groups on Nano Science has been created. These centres of excellence contain sophisticated facilities for sharing with other scientists in the region and helps in promoting scientific research on nanoscale systems in a decentralized fashion. Fig. 4 illustrates centers of excellence that have been set up in various locations in India [13]. 


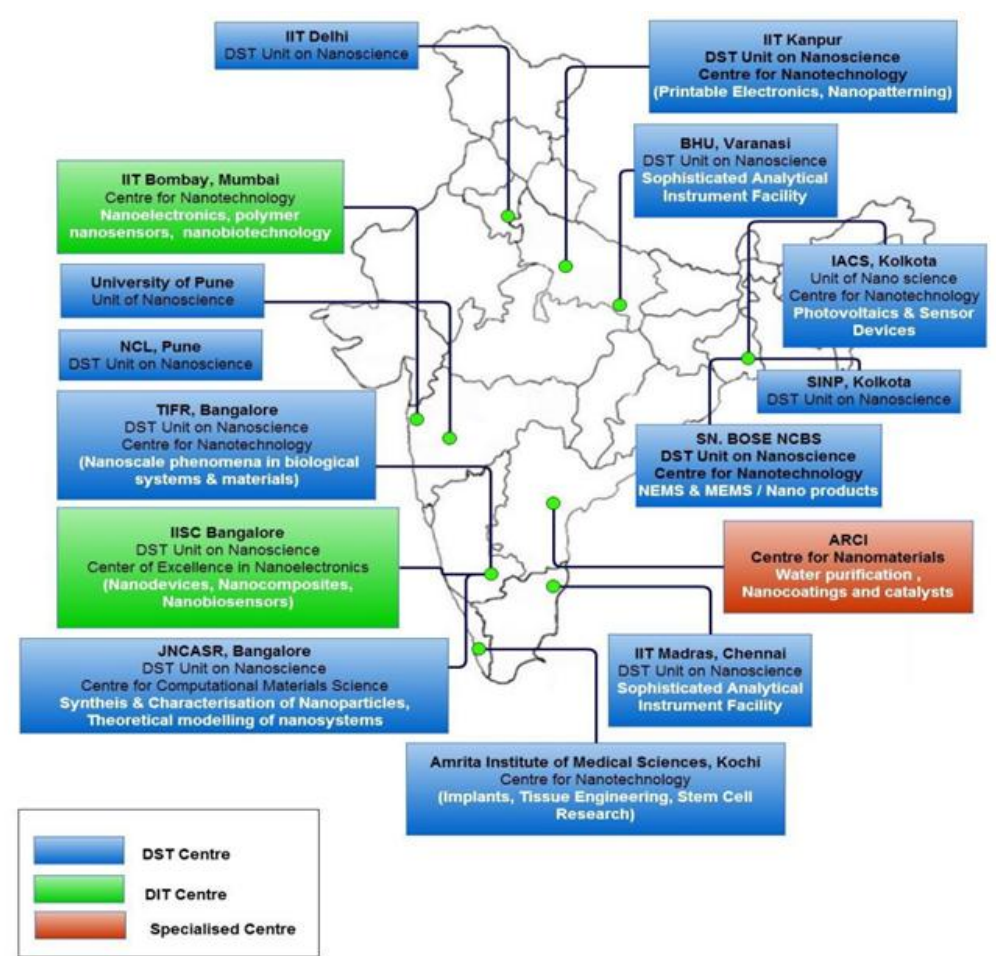

Fig. 4 : Nanotechnology centres of excellence in India

\section{Challenges Of Nanotechnology Innovation In India}

The broad implication of Nanotechnology for society can be grouped into two categories, namely environmental, health and safety implications and societal \& economic dimensions. There are several issues emerge in the nanotechnology development in India (TERI, 2010) [25]:

- Early research indicates that nanoparticles could reach various parts of the body where they may exert adverse effects. Nanoparticles, it is believed might be able to disrupt cellular, enzymatic and other organ related functions posing health hazards. On the other hand nanoparticles might also be non-biodegradable and on disposal, these disposed materials might form a new class of non-biodegradable pollutant and pose a new threat to the environment (air, water, soil) and health.

- Even where risk aspects are looked at, several gaps and challenges exist in the sphere of undertaking studies related to toxicity and EHS impacts. These include lack of information on the nature and characteristics nanomaterials in applications, insufficient methods for detecting and measuring nanomaterials, inadequate breadth of risk related research.

- The improvement of efficiency, reliability, safety and lifetime, as well as the reduction of costs are the main challenges for the application of nanotechnology.

- The interdisciplinary nature of nanotechnology and the scope of its applications is one of the biggest challenges. This has led to significant overlaps in the areas to R\&D support identified by different agencies.

- There is poor lab firm integration, which is compounded by the scarcity of skilled manpower that could provide linkages between the technology and commercial domains. This gap between basic research and application is another challenge in nanotechnology.

- High nanotechnology costs for acquisitions of intellectual property rights, nanotechnology infrastructure, lack of human and policy capacity, financial constraints often act as an impediment in this regard.

- The main challenges faced by regulatory institutions currently relate to the regulatory capacity, information asymmetry and absence of inter-agency coordination.

Development of an adequate risk governance framework for addressing risks that surround nanotechnology is vital for the responsible development of nanotechnology that allows reaping benefits while minimizing risks [1, 26-27].

\section{Towards Responsible Nanotechnology Development}

Whereas, in several other countries involved in nanotechnology R\&D, issues of risk had become an area of attention, for a long time in India the focus remained almost exclusively on the benefits[4,28]. Regarding the regulatory aspects many researchers are of the view that the government is very sloppy in establishing a regulatory body to predict the safe development and commercialisation of nanotechnology 
products [29-31]. Few others have also raised the issue of labelling of nano-based products to enable people make an informed choice. The government of India announced the establishment of a regulatory board for nanotechnology in 2010. Various existing Indian laws/regulations that need relevant and timely interventions/changes to include nanotechnology related consequences can be classified into the following categories (TERI 2010):

- Production and Marketing: Drugs and Cosmetics Act, 1940, National Pharmaco vigilance Protocol, Medical Devices Regulation Bill, and Insecticides Act, 1968.

- Occupational Health and Safety: Factories Act, 1948 and OHS under other legislation.

- Environmental Risk Management: Pollution control laws, Environment Protection Act, and Public Liability Insurance Act.

- Waste Disposal: Factories Act, Hazardous Material (Management, Handling and Transboundary Movement) Rules 2007, Bio-Medical Waste (Management and Handling) Rules 1998, Municipal Solid Wastes Rules 2000.

As of now, there has been no effort made to streamline these acts/rules in order to address risks related to nanotechnology. The DST has recently made efforts towards establishing of a regulatory system. The Nano Mission has organised national dialogues to promote R\&D in development of standards for nanotechnology and for laying down a National Regulatory Framework Road-Map for Nanotechnology (NRFR-Nanotech) (PIB 2014).

\section{Conclusion}

Nanotechnology could be both relevant and appropriate to sustainable development practices in India. The development of Nano science and technology in India has huge potential to help the country address societal challenges such as provision of drinking water, healthcare, etc., and simultaneously achieve economic gains through growth in the nanotech-based industrial sector. There is also a danger in viewing nanotechnology as a solution to developing country challenges. Therefore, it is necessary to develop responsible nanotechnology governance, encourage the development of appropriate products targeted to help meet critical human development needs, and include methods for addressing the safety, appropriateness; accessibility and sustainability of nanotechnology meet the developing countries like India. India's early involvement with various international/ inter-governmental organisations, such as International Standards Organisation (ISO), Organisation for Economic Cooperation and Development (OECD), and IRGC, for the development of standards, safe lab practices and risk governance is quite significant.

\section{References}

[1] Nanotechnology development in India: building capability and governing the technology [TERI Briefing Paper], TERI 2010.

[2] The National Nanotechnology Initiative Strategic Plan, Nanoscale Science, Engineering, and Technology Subcommittee, National Science and Technology Council, The White House December 2007.

[3] A. Dhawan, V. Sharma and D. Parmar, Nanomaterials: A challenge for toxicologists, Nanotoxicology, 3, 2009,1-9.

[4] Koen Beumer and Sujit Bhattacharya, Emerging technologies in India: Developments, debates and silences about nanotechnology, Sci Public Policy, 40 (5), 2013, 628-643.

[5] S. Mazumder, D. Sarkar and I.K. Puri, Nanotechnology Commercialization: Prospects in India, Journal of Materials Science \& Nanotechnology, 2 (2), 2014, 1-11.

[6] M. Ratner and D. Ratrner, Nanotechnology: A general introduction to next big idea, New Jersey, Prentice Hall, 2002.

[7] M.C. Roco, Towards a US national nanotechnology initiative, J Nanoparticle Res, 1, 1999, 435-8.

[8] G.Whitesides and C. Love, Implication of nanoscience for knowledge and understanding, Dordrecht, Netherland, Kluwer Academic Publishers, 2001.

[9] A. Aviram and M. Ratner, Molecular rectifiers, Chem Phys Lett, 29, 1974, 277-83.

[10] G. Binnig and H Rohrer Scanning tunnelling microscopy, IBM J Res Devel, 30, 1986, 355

[11] S Iijima Helical microtubules of graphitic carbon, Nature 354, 1991, 56-8.

[12] C. Mao, W. Sun, Z. Shen and N.C. Seeman, A nanomechanical device based on the B-Z transition of DNA, Nature 397, 1999, 144-6.

[13] Sujit Bhattacharya, A. Jayanthi, Pushkaran and Shipla, Nanotechnology Development in India investigating ten years of India's efforts in capacity building CSIR- NISTADS Strategy paper I: July 2012.

[14] S. Bhattacharya, and M. Bhati, China's Emergence as a Global Nanotech Player: Lessons for Countries in Transition, China Report, 47 (4), 2011.

[15] D.C. Maclurcan, Nanotechnology and Developing Countries Part 2: What Realities?" AZoNano - Online Journal of Nanotechnology, 1, 2005.

[16] Amit Kumar, Nanotechnology Development in India An Overview RIS-DP \# 193, 2014

[17] The Energy and Resources Institute (TERI), Review of international nanotechnology developments and policy concerns, 2009.

[18] M.C. Roco, The NNI: Past, Present and Future, in Goddard, W.A et al. (ed.) Handbook on Nanoscience, Engineering and Technology, CRC, Taylor and Francis, Boca Raton and London, 2007, 3.1-3.26.

[19] The Energy and Resources Institute (TERI). 2009 Nanotechnology developments in India - a status report TERI project: Capability, Governance, and Nanotechnology Developments - a focus on India.

[20] S. Bhattacharya, M. Bhati and A.P. Kshitij, Investigating the Role of Policies, Strategies, and Governance in China's Emergence as a Global Nanotech Player. IEEE Conference Proceeding of the 2011 Atlanta Conference on Science and Innovation Policy 
(http://ieeexplore.ieee.org/xpls/abs_all.jsp?arnumber=6064462), 2011.

[21] GOI. 1998. 9th Five-Year Plan 1998-2002. Planning Commission, Government of India. New Delhi: SAGE Publications India Pvt Ltd.

[22] DST. 2001. Annual Report 2000-01. Department of Science and Technology (DST), Government of India, New Delhi.

[23] GOI. 2007. 11th Five-Year Plan 2007-2012. Planning Commission, Government of India. New Delhi: SAGE Publications India Pvt Ltd.

[24] Shefali, Rahul Gangwar, Mona Devi, Priya Chhabra and B. Prasad, Role of Nano Science in Development of India, National Conference on 'Role of Science and Technology Towards Make in India, YMCA University of Science and Technology, Faridabad (Haryana), 2016.

[25] Azamat Ali and Dr. Kunal Sinha, Exploring the Opportunities and Challenges in Nanotechnology Innovation in India, Journal of Social Science for Policy Implications, 2(2), 2014, 227-251

[26] H. Purushotham, and K. Madhuri, Knowledge management and regulation issues: Key for sustainable development of nanoscience and technology in India, Proceedings of International Conference on Nanoscience, Engineering and Technology (INCONSAT), IEEE, 2011, 78-83.

[27] H. Purushotham, Transfer of nanotechnologies from R\&D institutions to SMEs in India: Opportunities and challenges. Centre for Knowledge Management of Nanoscience (CKMN) and Technology Advanced Centre for Powder Metallurgy and New Materials (ARCI) Hyderabad, Andhra Pradesh, India, 2012

[28] N. Srivastava, N. Chowdhury, Regulation of health related nano applications in India: Exploring the limitations of the current regulatory design, International Conference on Mapping the Uncertainty of Nanotechnology Challenges to Law, Ethics and Policy Making, University of Padua, Italy, 2008.

[29] Nupur Chowdhury, Regulatory Supervision of Emerging Technologies: A Case for Nanotechnology in India, Economic a Political Weekly, 2006, 4730-4733.

[30] S.D. Sarma, How resilient is India to Nanotechnology risks?, European Journal of Law and Technology, 2 (3), $2011,1-15$.

[31] A.P. Jayanthi, K. Beumer, M. Bhati, and S. Bhattacharya. 2012. "Nanotechnology: 'Risk Governance' in India". Economic and Political Weekly, Vol. XLVII(4), 2012, 34-40 